\title{
Minnesota settlement, documents in mind-boggling numbers, smoke-free Birmingham, fire-safe cigarettes, Surgeon General's report, nicotine yields, cigars, Tasmania, and a Marlboro Gear spoof
}

Web Watch follows issues relevant to tobacco control on the world wide web. The emphasis is on new sites or new features appearing on the web, including relevant URLs and short descriptions of the material. A web site is available featuring the URL links referenced in this column as well as those referenced in past columns; the URL for that site is: <http://www. gate.net/ jcannon/webwatch/>.

\begin{abstract}
Minnesota settlement
$<$ http://www.ag.state.mn.us/>

Details of the historic settlement of the lawsuit by the Minnesota attorney general (AG) and Blue Cross and Blue Shield of Minnesota against the tobacco industry are available on the Minnesota AG's website. Summary sheets entitled "At a glance", "Overview", "Truth", "Health", "Reform", "Kids", and "Money" have been prepared to assist the viewer in understanding various aspects of the settlement.

Unprecedented document discovery characterised the Minnesota case, and thousands of documents obtained by the plaintiffs in this litigation are publicly available - many of them online at sites maintained by the United States House of Representatives, Blue Cross and Blue Shield of Minnesota, and even the tobacco industry (see below).
\end{abstract}

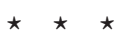

\section{Documents released on 22 April} 1998

<http://www.house.gov/commerce/TobaccoDocs/ documents.html>

In a follow up to the last Web Watch column regarding the release of "more than 800 additional Liggett documents", the Commerce Committee of the House of Representatives in the United States has released 39000 more subpoenaed documents (figure 1) from the now-settled Minnesota lawsuit discussed above.

Subpoenaed from the Council for Tobacco Research, Brown and Williamson, Philip Morris, RJ Reynolds, Lorillard, and the Tobacco Institute after the companies refused to voluntarily turn them over, these documents are believed to be the most damaging ever released against the tobacco industry.

Documents from Blue Cross and Blue Shield of Minnesota

Web Watch is prepared by fack Cannon. Send correspondence to jcannon@gate.net trialnews $>>$

Supplementing the Minnesota AG's website, Blue Cross and Blue Shield of Minnesota
(BCBSM) provides additional information on the settlement.

Click on "Updates" for summaries of important courtroom events.

Before the release of the 39000 subpoenaed documents, BCBSM, a co-plaintiff in the Minnesota Medicaid liability suit, released these 20 particularly damaging documents. Unlike many other sites, a detailed description for each of these documents is provided. Four categories are available: "Smoking and health", "Nicotine addiction", "Nicotine manipulation", and "Marketing to kids".

A "Sampler of the 39000 documents" provides additional insight into those formerly protected by attorney/client privilege. The category "Documents sorted by chronology" contains an extensive list of documents made public during the trial.

Finally, a search engine and plaintiff witness list are available.

\section{Tobacco resolution}

<http://www.tobaccoresolution.com/>

Thursday, 30 January 1998-Appearing before the United States House Commerce Committee, Philip Morris chairman Geoffrey Bible surprised everyone to win favour in Congress for tobacco industry immunity.

"We will immediately take steps to make all documents public", he said, referring to the 33 million papers the tobacco industry filed in Minnesota's litigation against Philip Morris and its allies.

Addressing Lorillard chairman Lawrence Tisch, committee chairman Thomas Bliley asked, "Mr. Tisch, do you support this decision to release the papers"?

"I, I think so. I don't, I really don't know too much about it but it, it, it sounds as if ... I have uh, confidence in Mr Bible's decision-making process and if he thinks it's the right thing to do I, I affirm it", was the startled reply.

This affirmation formed the impetus for the tobacco resolution web site, which serves primarily as a gateway to six other sites-each under the control of the respective organisation 


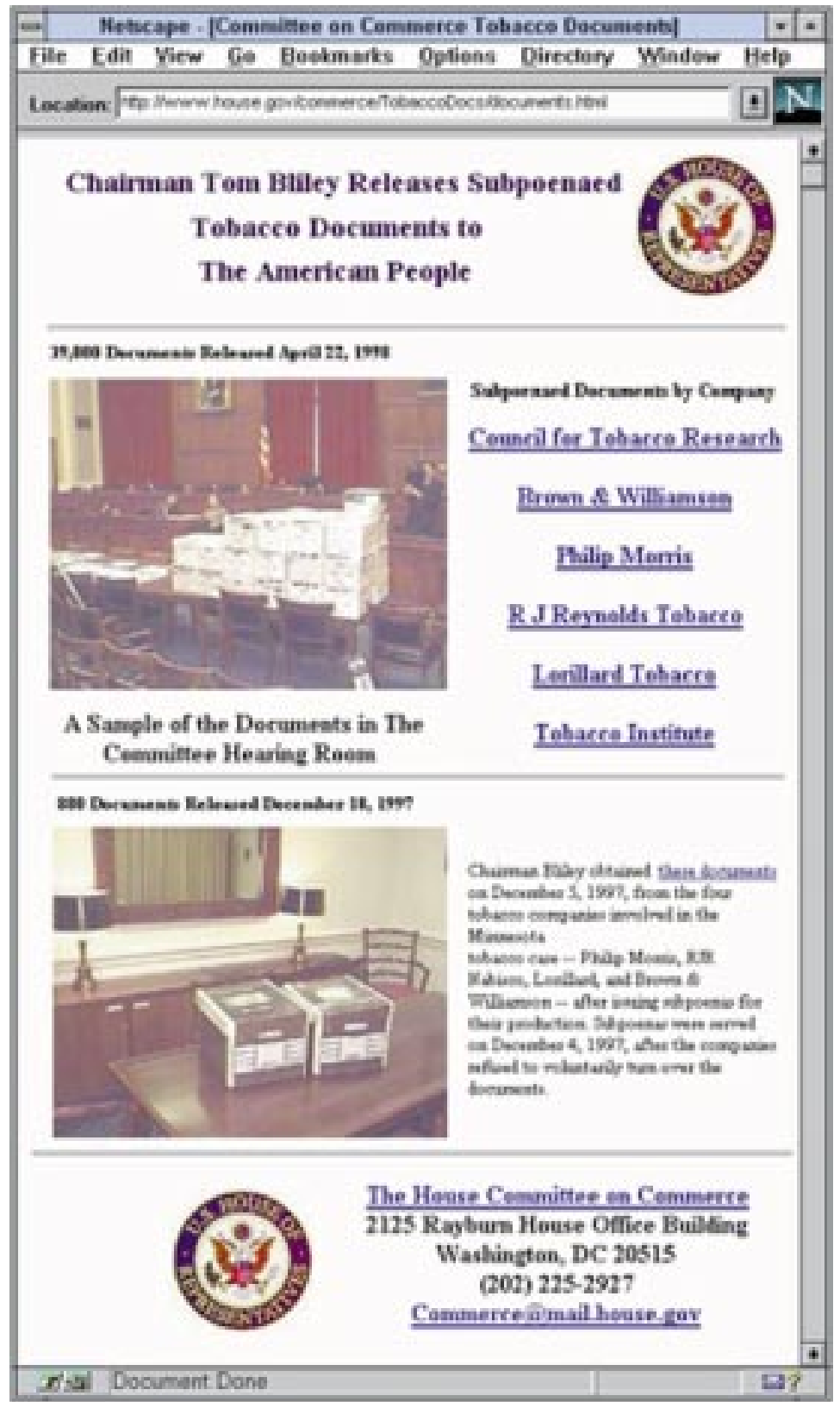

Figure 1 Web site for the subpoenaed documents of the Commerce Committee of the United States House of Representatives.

and each with independent search mechanisms for locating documents. Those sites are:

- Lorillard

$<$ http://www.lorillard.com/>

- Brown and Williamson (including the American Tobacco Company)

$<$ http://www.bw.aalatg.com/main.htm>

- Philip Morris

$<$ <ttp://www.philipmorris.com/>

- RJ Reynolds

$<$ http://www.rjrt.com/>

- The Tobacco Institute

$<$ http://www.tobaccoinstitute.com/>

- The Council For Tobacco ResearchUSA, Inc

$<h t t p: / / w w w . c t r-u s a . o r g / c t r />$

Philip Morris, Lorillard, and the Tobacco Institute present the documents as standard GIF (graphics) files, which are compatible with web browsers. However, RJ Reynolds and
Brown and Williamson use another graphics format known as TIFF, which is not readable by most web browsers.

A TIFF viewer is available and can be downloaded from

$<$ http://www.filenet.com/prods/watermark/plugin/ download.html>.

However, this viewer is only available for Windows 95 and Windows NT.

It would seem as though Windows 3.1 users would be out of luck, but an alternative is available by saving the TIFF file to disk and then viewing it offline using one of the commercially available graphics programs.

Many users are reporting problems with the TIFF viewer, particularly if an attempt is made to print the file. Given such considerations it may be preferable to save the files and view/print them offline regardless of whether the browser is operating under Windows 95.

Conspicuously noticeable within the results of searches is an overwhelming abundance of industry press releases and advertisements. It is likely that these documents were not considered to be privileged but were included to impede searches.

Slow response time and restrictions on keyword usage coupled with industry inclusion of public documents seriously erode the ability to conduct search attempts, leaving the user frustrated with non-productive attempts to locate documents of significance.

One document that was uncovered is a letter confirming the contractual relationship between Philip Morris and the producers of the movie Superman II for the placement of Marlboro cigarettes in numerous scenes within the movie. To ensure that the letter is easy to find, it is mirrored at

<http://www.gate.net/ jcannon/superman.html> along with a textual transcription of the letter.

\section{Birmingham (United Kingdom) campaign \\ $<$ Lttp://www.smokefree.org.uk/>}

Can Birmingham really become the United Kingdom's first "smoke-free city"?

With support from the minister for public health, the Birmingham campaign has launched this new and developing web site for the dissemination of information to accomplish the smoke-free objective.

Because all secondary schools in Birmingham plus many primary schools, most libraries and other public service organisations are connected to the internet, this site is a natural for promoting the Guide to smoke free Birmingham. This extensive compendium of smoke-free establishments features cafés, restaurants, public houses, banks, garages, sports facilities, schools, and governmental institutions.

An impressive gallery of anti-tobacco graphics is featured. These include both the campaign's own images and those produced by the national freephone (toll-free) Quitline service (see figure on next page).

An innovative feature of the Birmingham site is the offerings of special deals to sports, arts, 




Figure 2 A poster from the national freephone (toll-free) Quitline service in the United Kingdom, as displayed on the Smoke Free Birmingham web site.

and cultural events, an innovative strategy to attract young people to the site.

Encouragement is also extended to young journalists to get involved in the production of materials for the site. This introduction to journalism features the work of teenagers and children. From Louise Madden (age 16), "Eternal don't do it, 4 out of 5 Spice Girls do it! SMOKING!"”

More information on the Birmingham campaign appears in the cover essay in this issue of Tobacco Control, on pages 112-115.

BMJ-medicine and the media <http://194.216.217.166/archive/7135/

$7135 \mathrm{~mm} . \mathrm{htm}>$

DATELINE LONDON, 8 March 1998: "Passive smoking doesn't cause cancer-official" screams the headlines from the Sunday Telegraph and the Sunday Times. For the truly gullible among Sunday Telegraph readers, the claim was asserted that a study commissioned by the World Health Organisation's International Agency for Research on Cancer (IARC) produced findings that "could be consistent with passive smoke having a protective effect against lung cancer".

How could this study of 650 lung cancer cases and 1542 controls be promoted as possible protection against lung cancer when, in fact, it found a $16-17 \%$ increased risk of lung cancer in non-smokers exposed to environmental tobacco smoke?

Interjecting himself into this prattle in an article published by the British Medical fournal,
Tobacco Control's deputy editor Simon Chapman examines the enigma. He finds that these astounding pronouncements are based on a gross misinterpretation of the confidence intervals surrounding the study's risk estimates (also see page 120 in this issue).

The real question, of course, is, "Who is the spin doctor?"

\section{Fire-safe cigarettes}

$<$ http://www.waltman.com/PhilipMorris/ pmdocs.html>

<http://www.latimes.com/HOME/NEWS/BUSINESS/ tobac1.htm>

On 27 March 1994, the CBS programme 60 Minutes aired an investigative segment on Philip Morris' super-secret "Project Hamlet". The goal of Project Hamlet: to develop a fire-safe cigarette that would be acceptable to smokers.

Although the tobacco companies say they don't know how to make a fire-safe cigarette that would be acceptable to consumers, CBS quoted numerous, secret, internal Philip Morris documents showing no significant differences between the Project Hamlet prototype and a Marlboro.

Now comes the Texas law firm of Waltman and Grisham representing Vicki Stacks as a friend of Shannon Moore, a three-year-old girl who was burned over $80 \%$ of her body by a carelessly discarded cigarette-a horrific injury that allegedly could have been prevented had Philip Morris simply incorporated its existing technology to remove the design defects that resulted in this needless disfigurement.

Depositions of numerous, key Philip Morris researchers directly involved in Project Hamlet have been posted on this firm's web site.

In addition to the depositions, the firm has collected more than 100000 pages of internal documents from Philip Morris and can share these documents with legal counsel of any other plaintiff who has filed suit against Philip Morris for injury or damage resulting from a fire allegedly caused by a cigarette manufactured by Philip Morris.

The Los Angeles Times has released secret industry documents generated by the Tobacco Institute that not only discuss the feasibility of producing fire-safe cigarettes, but also the industry's lobbying strategies to counter legislation that would require cigarettes to be fire safe.

Massachusetts nicotine disclosure report <http://www.cancer.org/tobacco/nicotinereport/ toc.html >

More than 30 years have passed since the United States Federal Trade Commission (FTC) developed the national standard for testing the tar and nicotine yields of cigarettes. Following adoption of the FTC standard, the tobacco industry substantially altered the design of cigarettes, resulting in a significant loss of correlation between tar and nicotine yields measured by the FTC methodology and those actually delivered to the smoker.

The Massachusetts Department of Public Health (MDPH) has established testing 
standards for nicotine yield ratings which accurately predict smoker intake. By state law, tobacco manufacturers must file an annual report based on $\mathrm{MDPH}$ testing standards for each brand of tobacco product sold in Massachusetts. These standards have revealed nicotine yield levels about twice as high as those indicated by the FTC method.

Eighty-five cigarette brands have been tested by MDPH. A startlingly finding-no brands tested fell into the low or nicotine-free classification! The report is available at the above URL, which includes a detailed analysis of nicotine yield testing, nicotine content of whole tobacco, percent filter ventilation, and nicotine yield ratings.

$$
\star \star \star ~
$$

\section{Cigars: Health effects and trends}

<http://rex.nci.nih.gov/NCI_MONOGRAPHS/

MONO9.HTM>

In the most scathing indictment ever issued against cigars, the National Cancer Institute has released a report saying that cigars can be just as lethal as cigarettes, causing cancers of the lip, tongue, mouth, throat, larynx, oesophagus, and lung, as well as chronic obstructive pulmonary disease and coronary heart disease.

Donald R Shopland, who coordinates NCI's smoking and tobacco control programme, ranks the importance of this report as similar to the original report of the Surgeon General in 1964 on cigarettes. "This is the most comprehensive assessment of what we know about the health risks and trends of cigar smoking in this country," he said.

The press release is available at $<$ http://rex.nci.nih.gov/massmedia/pressreleases/ cigar.htm>.

The health effects of cigar smoking are the focus of one of the eight chapters making up NCI's new monograph, which is entitled Cigars: health effects and trends. To access a menu to the eight chapters go to

$<$ http://rex.nci.nih.gov/NCI_MONOGRAPHS/ MONO9.HTM>.

The monograph is in PDF format, whose total file size is 4700 kilobytes. Although the individual chapters are smaller and can be individually accessed, it is probably better to start with the background information available as a question and answer series at $<$ http://rex.nci.nih.gov/massmedia/backgrounders/ cigarbk.htm>.

Tasmania delivers serious blow to the tobacco industry

$<h t t p: / / w w w . d c h s . t a s . g o v . a u / m o r e i n f o /$ tobintro.html >

Think that the American judicial system has the tobacco industry sweating? Don't overlook what is happening in the Australian State of Tasmania.

On 12 December 1997, the Tasmanian parliament unanimously passed a public health law that may well set the standard to which other legislatures aspire.

Check out this message from the Honorable Peter McKay MLC, Tasmanian minister for community and health services, for a description of the serious advertising restrictions Tasmania has imposed against the tobacco industry.

Equally serious are the sanctions imposed against selling tobacco products to children.

The text of the relevant part of this tobacco control legislation is online at

<http://www.dchs.tas.gov.au/moreinfo/tobleg.htm>.

\section{Report of the Surgeon \\ General-Tobacco use among US raciallethnic minority groups}

$<h t t p: / / w w w . c d c . g o v / n c c d p h p / o s h / s g r-$ minorities.htm>

Available online in PDF format, this Surgeon General's report addresses patterns of tobacco use, health consequences, industry marketing and other factors influencing tobacco use, and tobacco control and educational efforts among members of the four major American racial/ethnic minority populations: African Americans, American Indians and Alaska Natives, Asian Americans and Pacific Islanders, and Hispanics.

The executive summary of the report is reproduced in this issue of Tobacco Control, on pages 198-209.

\section{Marlboro Gear spoof}

<http://www.fadetoblack.com/marlboro/> Fade to Black is an online comedy magazine that made its debut last year. Featuring satirical subjects, the magazine's articles are guaranteed to be considered offensive by at least someone in the public eye. The tobacco industry and its supporters are no exception.

Based on the Philip Morris Marlboro Miles promotional campaign, the Marlboro Political Buyer's Guide is a spoof on the tobacco industry's ability to buy the influence of politicians and organisations.

Using a formula derived by averaging out the price of an item in a Marlboro catalogue and comparing the result with the amount of Marlboro Miles needed to purchase it, Fade to Black determined that the retail value of a Marlboro Mile is approximately US $\$ 0.05$.

The formula was then used to determine the number of Marlboro Miles required to buy the influence of Bob Dole, Jesse Helms, the American Red Cross, and the law firm that attempted to pass a California law (Proposition 188) to loosen tobacco restrictions. Example: 8 million Marlboro Miles are required to purchase Bob Dole's claim asserted on national television that nicotine is not addictive.

But that's not all!

Using actual items taken from the Marlboro Unlimited Gear catalogue, Fade to Black calculated the total number of Marlboro Miles one would acquire by smoking enough to inflict various tobacco-related maladies.

Victims need only to locate their particular illness from the convenient list and view the corresponding prizes for which eligibility could be claimed. Based on smoking two packs a day for 30 years, a tracheotomy would net the lucky winner 48 mountain bikes and three Swiss army knives plus a pair of sunglasses! 